\title{
New trends in non-invasive prenatal diagnosis: Applications of dielectrophoresis-based Lab-on-a-chip platforms to the identification and manipulation of rare cells (Review)
}

\author{
MONICA BORGATTI, NICOLETTA BIANCHI, IRENE MANCINI, \\ GIORDANA FERIOTTO and ROBERTO GAMBARI
}

Biotechnology Center and ER-GenTech, Department of Biochemistry and Molecular Biology,
University of Ferrara, Ferrara, Italy

Received June 7, 2007; Accepted July 16, 2007

\begin{abstract}
The isolation of rare cells, such as fetal nucleated red blood cells and trophoblasts, from maternal blood for noninvasive prenatal diagnosis is a new field of research exhibiting several difficulties since this strategy requires unresolved basic technological protocols for a successful outcome. However, several achievements in the field of Laboratory-on-a-chip (Labon-a-chip) technology have provided clear advancements in projects aimed at the isolation of rare cells from biological fluids. Among the most interesting approaches are those based on dielectrophoresis (DEP). DEP-based Lab-on-a-chip platforms have been demonstrated to be suitable for several applications in biotechnology and biomedicine. DEP-based arrays are able to manipulate single cells, which can be identified and moved throughout the DEP chip to recovery places. DEP buffers are compatible with molecular interactions between monoclonal antibodies and target cells, allowing integration of these devices with magnetic cell sorting (MACS). DEP treatment does not alter the viability of manipulated cells.
\end{abstract}

\section{Contents}

1. Introduction

2. Intact fetal cells in maternal blood: A short history

3. Isolation of intact fetal nucleated red blood cells in maternal blood: The state of the art

4. Isolation of trophoblasts in maternal blood: New trends

5. In the search of a partner for MACS: Theory and biotechnological applications of dielectrophoresis (DEP)

6. Lab-on-a-chip with high-density arrayed electrodes

Correspondence to: Professor Roberto Gambari, Department of Biochemistry and Molecular Biology, University of Ferrara, Via Fossato di Mortara n.74, 44100 Ferrara, Italy

E-mail: gam@unife.it

Key words: prenatal diagnosis, dielectrophoresis, fetal nucleated red blood cells, trophoblasts
7. Competing technologies: Noncontact laser microdissection and pressure catapulting (LMPC) for isolation of single cells

8. Conclusions

\section{Introduction}

Current methods for the diagnosis of aneuploidy and monogenic disorders require invasive testing by amniocentesis, chorion villus biopsy or fetal blood sampling (1-4). These diagnostic techniques increase the frequency of fetal loss by $\sim 0.5 \%$ (5). One alternative way for obtaining information on the gestating fetus involves recovery of fetal material from maternal blood (6). Currently, two independent approaches have followed this direction, one aimed at the identification and analysis of fetal DNA (7-13); the other aimed at the identification of circulating fetal cells, including trophoblasts (14-16), nucleated fetal red blood cells (fNRBC) (17-20), and nucleated white blood cells (21). Among these cell types, the most promising appears to be the identification and isolation of fNRBC and trophoblasts. In particular, trophoblasts have been recently described as very promising, considering the fact that, despite being rare within the blood of pregnant women, they can be grown in vitro.

Until recently, no established and routine methods for isolation of fetal cells from maternal blood have been available (22). Therefore, the development of technological platforms able to singularly manipulate rare cells is of great importance.

\section{Intact fetal cells in maternal blood: A short history}

In 1969, Walknowska et al (23) described Y chromatin in blood cells from women carrying male fetuses. Ten years later, recovery of fetal leukocytes from maternal blood by fluorescence-activated cell sorting (FACS) with antibodies against paternally derived HLA antigens was reported (24). Schmorl (25) described the deportation of fetal trophoblasts to the lungs of pregnant women suffering from eclampsia. Trophoblast cells have not found widespread application in diagnostic studies because they are rapidly cleared by the maternal pulmonary circulation and are likely to exhibit confined chromosomal mosaicism (26). Nucleated red blood 
cells (NRBC) are the most common cells in fetal blood during early pregnancy. Since they have a relatively short half-life and express hematopoietic plasma membrane antigens, such as the transferrin receptor (CD71) and the glycophorin A cell surface molecule and intracellular markers ( $\varepsilon$ and $\gamma$ globin chains), fetal NRBC have become the targets of choice. In 1990, Bianchi et al (27) recovered fetal NRBC in maternal blood by using FACS. Fetal origin of the separated cells was confirmed by the presence of $\mathrm{Y}$ chromosome DNA, corresponding to the sex of the fetus.

\section{Isolation of intact fetal nucleated red blood cells in maternal blood: The state of the art}

Although the most represented fetal cells, fNRBC, are rare in respect to maternal cells, they can be enriched in maternal blood samples by using antibodies against specific fetal antigens or by physical methods such as gradient or electrophoretic mobility-based separations. Antibodies have been used with fluorescence-activated cell sorting (FACS) (28) or magnetic-activated cell sorting (MACS) (29). These methods exploit antigenic differences between cells. FACS is able to enrich cells with high purity so that slides with sorted cells can be readily scanned manually. It also allows multiparameter sorting and can be adapted for use with intracytoplasmic antigens. MACS, on the other hand, using magnetic beads coated with specific antibodies, is a faster bench-top technique better suited to process larger cell numbers. Both negative and positive selections can be performed on the same population of cells. Detection of levels of fetal cells with these two methods is however difficult in relation to the small numbers of circulating fetal cells and the loss of fetal cells during the enrichment procedures. Bischoff et al (30) reported a simple and rapid-density-based progenitor cell enrichment approach. The samples were labeled with a RosetteSep ${ }^{\mathrm{TM}}$ progenitor antibody cocktail to remove unwanted maternal white cells (mature T-cells, B-cells, granulocytes, natural killer, neutrophils and myelomonocytic cells). The cellular fraction collected was analyzed by either fluorescent in situ hybridization (FISH) or real time-PCR for the presence of intact fetal cells and to quantify Y-chromosome-specific DYS1 sequences, respectively. The accuracy of detection rates of the progenitor enrichment approach were 53-89\%, and fetal sequences were detected in the range 0.067-1.167 genome equivalents per milliliter of blood. This method targets progenitor cells that are not necessarily of the erythroid lineage and may also allow expansion in culture and characterization of the fetal cell types that circulate in maternal blood. Some lymphocytes are long lived, and with this approach there is concern that enriched progenitors may be the vestiges of previous pregnancies and do not represent the true fetal genetic status of the current pregnancy (30). Charge flow separation (CFS) is an antibody-independent selection method of fetal cells that relies on the behaviour of cells in an electric field and a buffer counterflow gradient (31). It is an automated rapid method that purifies NRBC from maternal blood, and $\sim 30 \%$ of these cells are fetal. For noninvasive prenatal diagnosis, NRBC from the fetus must be precisely identified. They are able to be distinguished from maternal cells by identifying paternal DNA sequences (32).
Table I. Antibodies used for NRBC isolation.

\begin{tabular}{|c|c|}
\hline Antibody/target & Reference \\
\hline CD71 & $\begin{array}{l}\text { Winichagoon P et al, } 2005 \text { (44) } \\
\text { Nagy GR et al, } 2005 \text { (45) } \\
\text { Christensen B et al, } 2005 \text { (6) } \\
\text { Al-Mufti R et al, } 2004 \text { (47) } \\
\text { Al-Mufti R et al, } 2004 \text { (48) } \\
\text { Al-Mufti R et al, } 2000 \text { (59) } \\
\text { Furusawa T et al, } 1998 \text { (66) } \\
\text { Navenot JM et al, } 1997 \text { (68) } \\
\text { Savion S et al, } 1997 \text { (69) }\end{array}$ \\
\hline $2 \mathrm{~F} 6.3$ & Fernandez A et al, 2005 (46) \\
\hline $\mathrm{HbF}$ & Kazama A et al, 1996 (70) \\
\hline $\mathrm{CD} 45 / \mathrm{CD} 14$ & $\begin{array}{l}\text { Christensen B et al, } 2005 \text { (6) } \\
\text { Wang Z and Liebhaber SA, } 1999 \text { (65) }\end{array}$ \\
\hline Glycophorin-A & $\begin{array}{l}\text { Collarini EJ et al, } 2001 \text { (52) } \\
\text { Choolani M et al, } 2001 \text { (43) } \\
\text { Sekizawa A et al, } 1999 \text { (64) } \\
\text { Ziegler BL et al, } 1995 \text { (71) }\end{array}$ \\
\hline CD45 & $\begin{array}{l}\text { Martel-Petit V et al, } 2001 \text { (55) } \\
\text { Jakobs ME et al, } 2000 \text { (57) } \\
\text { Di Naro E et al, } 2000 \text { (61) } \\
\text { Cunningham J et al, } 1999 \text { (63) }\end{array}$ \\
\hline$\gamma, \varepsilon$ and $\zeta$ hemoglobin chains & $\begin{array}{l}\text { Jackson L et al, 1993 (5) } \\
\text { Christensen B et al, } 2003 \text { (49) } \\
\text { Christensen B et al, } 2003 \text { (50) } \\
\text { Collarini EJ et al, } 2001 \text { (53) } \\
\text { Samura O et al, } 2000 \text { (58) } \\
\text { Sekizawa A et al, } 1999 \text { (62) } \\
\text { Mavrou A et al, } 2003 \text { (17) } \\
\text { Xu H et al, } 2001 \text { (54) }\end{array}$ \\
\hline Glycophorin-C & Choi JW et al, 2002 (51) \\
\hline Embryonic hemoglobin (HbE) & Sekizawa A et al, 2000 (56) \\
\hline$\zeta$ hemoglobin chains & Al-Mufti R et al, 2000 (60) \\
\hline FB3-2; H3-3; 2-6B/6 & Pezzolo A et al, 1997 (67) \\
\hline
\end{tabular}

This method can be extended using micromanipulation of candidate fetal cells and amplification of chromosomespecific short tandem repeats (33). It is under investigation whether recovery of fetal cells with CFS is higher than that obtained with other separation methods. The most important molecular techniques that have allowed genetic analysis of enriched fetal cells are PCR and FISH. The ability of PCR to amplify minute quantities of DNA (even a single copy) $>1$ billion-fold has been exploited for the prenatal diagnosis of monogenic disorders from maternal blood (34-36). Chromosomal FISH allows the detection of aneuploidy and chromosomal rearrangements in interphase nuclei. It has been used to detect most of the major fetal aneuploidies within fetal cells isolated from maternal blood (28,37-39). Fetal traits which have been identified so far among the separated fetal cells include blood group antigen, the common trisomies, 


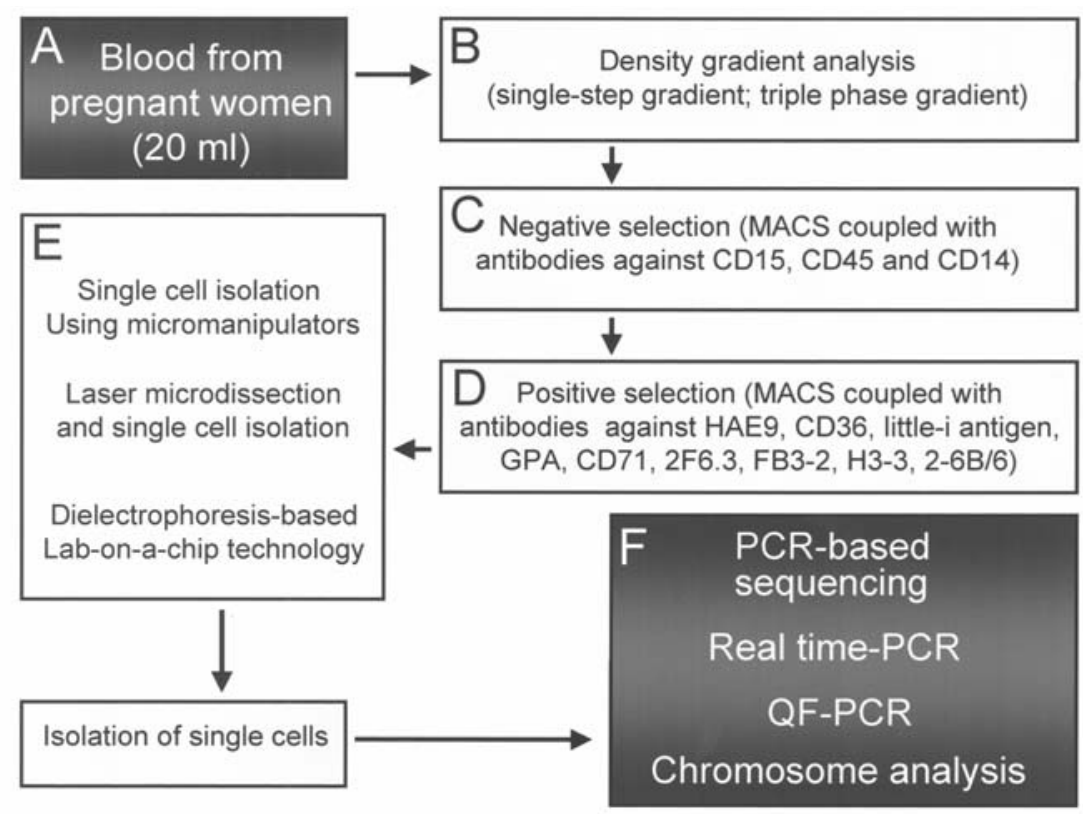

Figure 1. Flow chart depicting the strategy for enrichment of fetal cells from maternal blood for diagnostic purposes.

triploidy, polymorphic DNA repeats, and some single-gene disorders $(34,39-42)$. All of these methods result in the enrichment of fetal cells among larger populations of maternal cells, but they do not enable recovery of pure populations of fetal cells. Experimental approaches which combine fetal cell identification with molecular genetic diagnosis with in situ techniques circumvent these limitations and are especially suited for automation (43). Unfortunately prenatal diagnosis from maternal blood is not practicable for $\sim 30 \%$ of pregnant women, because the NRBC are not recovered. It is then important to optimize enrichment identification end diagnostic protocols.

A partial list of antibodies used for NRBC isolation is provided in Table I.

\section{Isolation of trophoblasts in maternal blood: New trends}

The relevance of trophoblasts as target cells is under debate. Among the identified drawbacks are the following: a) trophoblasts are long-term circulating cells and, therefore, may originate from previous fetuses; b) trophoblasts; c) a high level of heterogeneity in the number of trophoblasts $/ \mathrm{ml}$ of maternal blood has been described. However, recent advances in the isolation of trophoblasts from maternal blood have demonstrated that the potential application of these cells in non-invasive prenatal diagnosis is high (72). Trophoblast cells are isolated by several methods related to surface antigen expression (e.g. expression of HLA-G) and cell size. The idea of trophoblasts as target cells has been rethought from a point of view that has not yet been pursued; the potential to grow in vitro under suitable experimental conditions, thereby improving fetal cell detection and, possibly, allowing diagnostic approaches based on metaphase chromosome analysis. Accordingly, the HLA-G-positive fraction of sorted cells can be sub-cultured, greatly facilitating studies in molecular biology.

\section{In the search of a partner for MACS and FACS: Theory and biotechnological applications of dielectrophoresis (DEP)}

All the available information indicates that MACS technology allows the collection of cell populations significantly enriched in fetal erythroblasts or trophoblasts $(19,30,73-75)$. A combination of the MACS procedure with other strategies for isolation of rare cells is highly needed to obtain almost a pure cell population. Up to now, an integrated system has not been available.

In Fig. 1, a possible flow-chart is depicted allowing enrichment of fetal cells from maternal blood for molecular or cytogenetic analysis. There is general agreement that at least $20 \mathrm{ml}$ of blood must be obtained in order to ensure pure cell populations for analysis (Fig. 1A). After density gradient separations (Fig. 1B) and negative selection (Fig. 1C) the cells of interest are partially purified using antibodies to surface antigens recognizing fetal cells (Fig. 1D). This step does not allow a purification of pure cell populations since most of the antibodies used recognize and co-purify adult cells. Therefore, further analyses should be proposed, based on the labeling of fetal cells on the one hand and on the manipulation of single cells on the other. Concerning the latter step, several approaches have been proposed including single-cell isolation using micromanipulators, laser microdissection and single-cell isolation and dielectrophoresis-based Lab-on-achip technology (Fig. 1E). After isolation of single cells, several molecular biological techniques have been described for molecular characterization of the fetal cell genome, including PCR-based sequencing, real time-PCR, and Quantitative Fluorescence PCR (QF-PCR) (Fig. 1F). In case the procedure allows further cell culturing steps, chromosomal analysis is feasible (Fig. 1F). Among the different technologies recently proposed for isolation of rare cells from a mixed population, this review focuses on dielectrophoresis (76). 

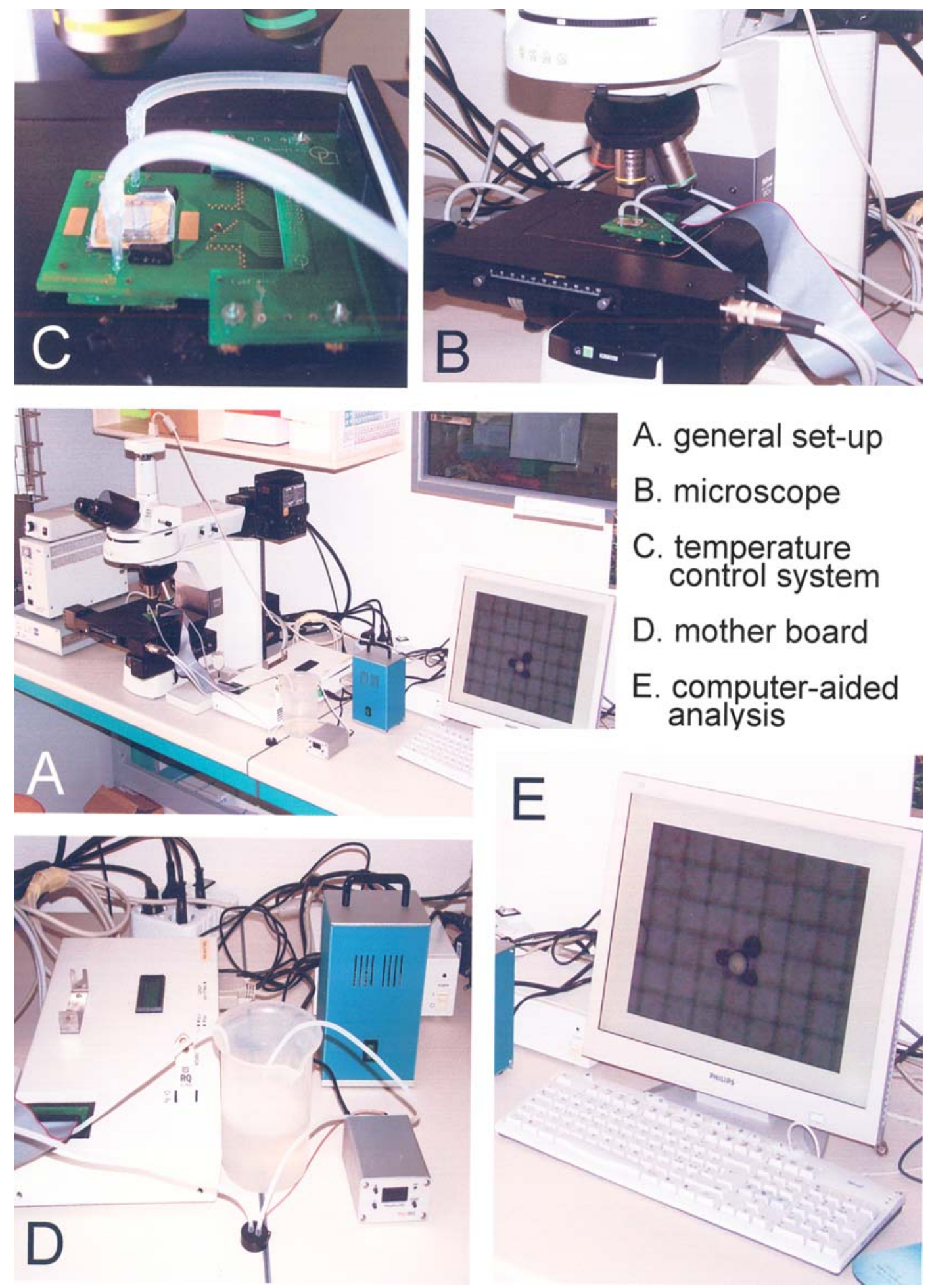

A. general set-up

B. microscope

C. temperature control system

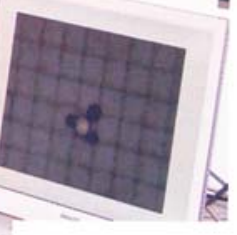

D. mother board

E. computer-aided analysis

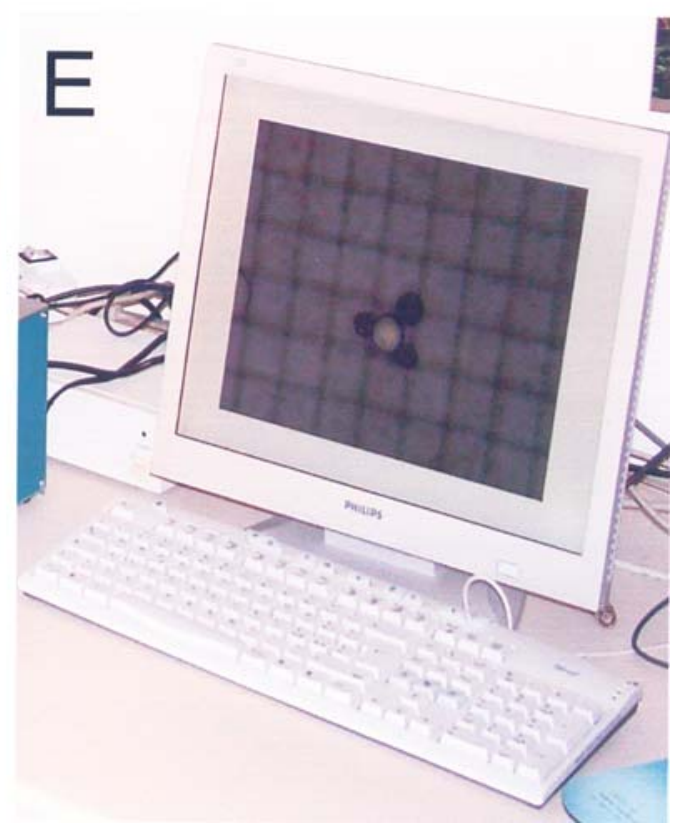

Figure 2. (A) Set-up of the Lab-on-a-chip assembly, consisting of a microscope (B), a micropump for temperature stabilization (C), a mother board (D), and a personal computer (E). Modified from Borgatti et al (97).

DEP is the movement of particles in non-uniform electric fields $(77,78)$. Charges in the particle itself are not necessary for the effect to occur. This is due to the fact that when an electric field is applied to a system consisting of particles suspended in a liquid, a dipole moment is induced, due to the electrical polarizations at the interface between the particle and the suspending liquid (77-83). If the field is non-uniform, the particles experience a translation force (DEP force) of magnitude and polarity, depending not only on the electrical properties of the particles and the medium, but also on the magnitude and frequency of the applied electric field. This means that for a given particle type and suspending medium, the particle can experience, at a certain frequency of the electrode applied voltages, a translation force directed towards regions of high electric field strength (this phenomenon is called pDEP). Alternatively, by simply changing the frequency, 

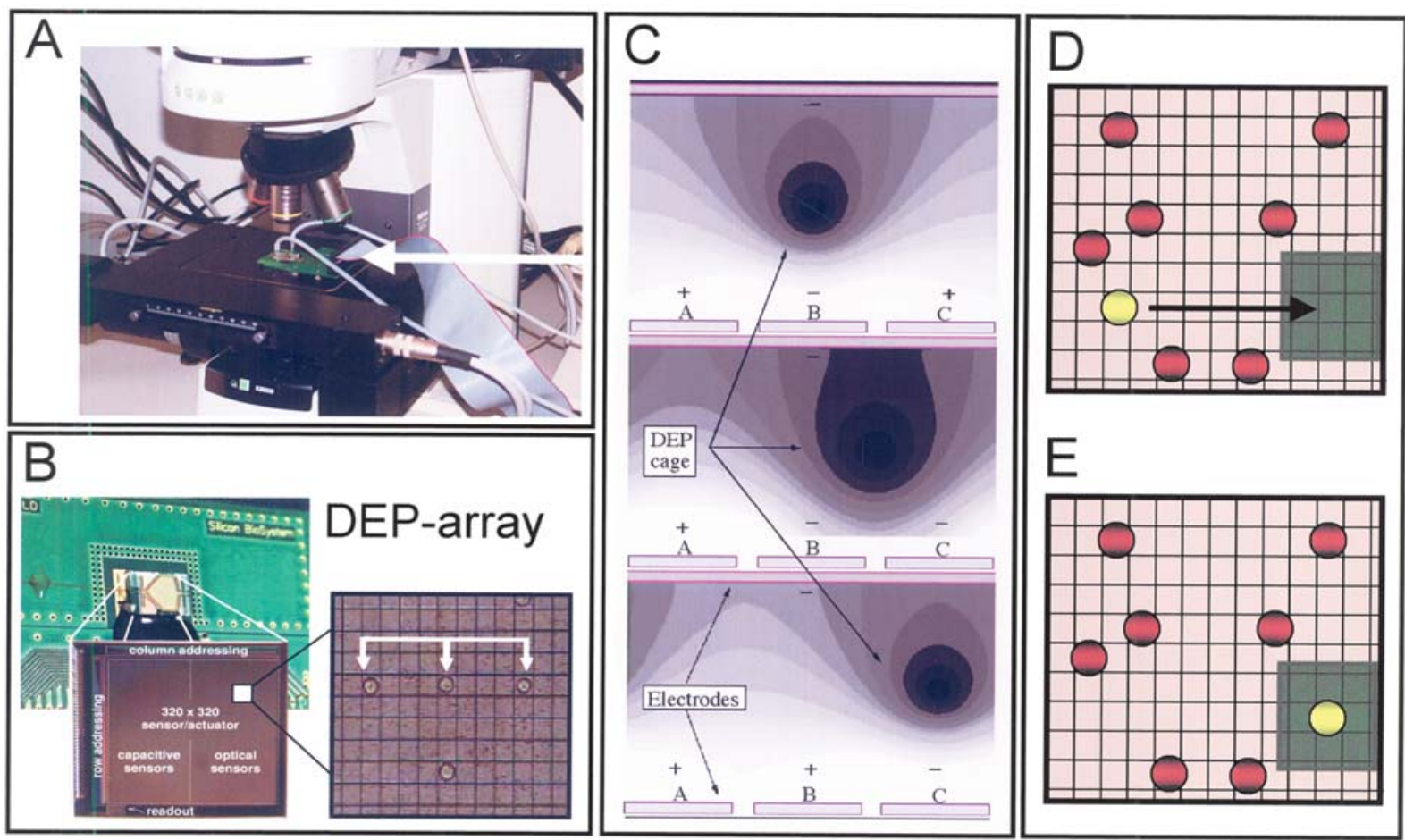

Figure 3. (A,B) Detail of structures of the DEP-array. The location of the device under the microscope is indicated with an arrow in panel A, while the structure is shown in panel B. In the insert of panel B, single cells are entrapped within DEP-cages and separated. (C) Simulation of the movement of a single spherical DEP-cage along the DEP-array. (D,E) Programmed routing of an identified single cell (yellow) to a recovery field (green). Panels A-C are modified from Borgatti et al (91).
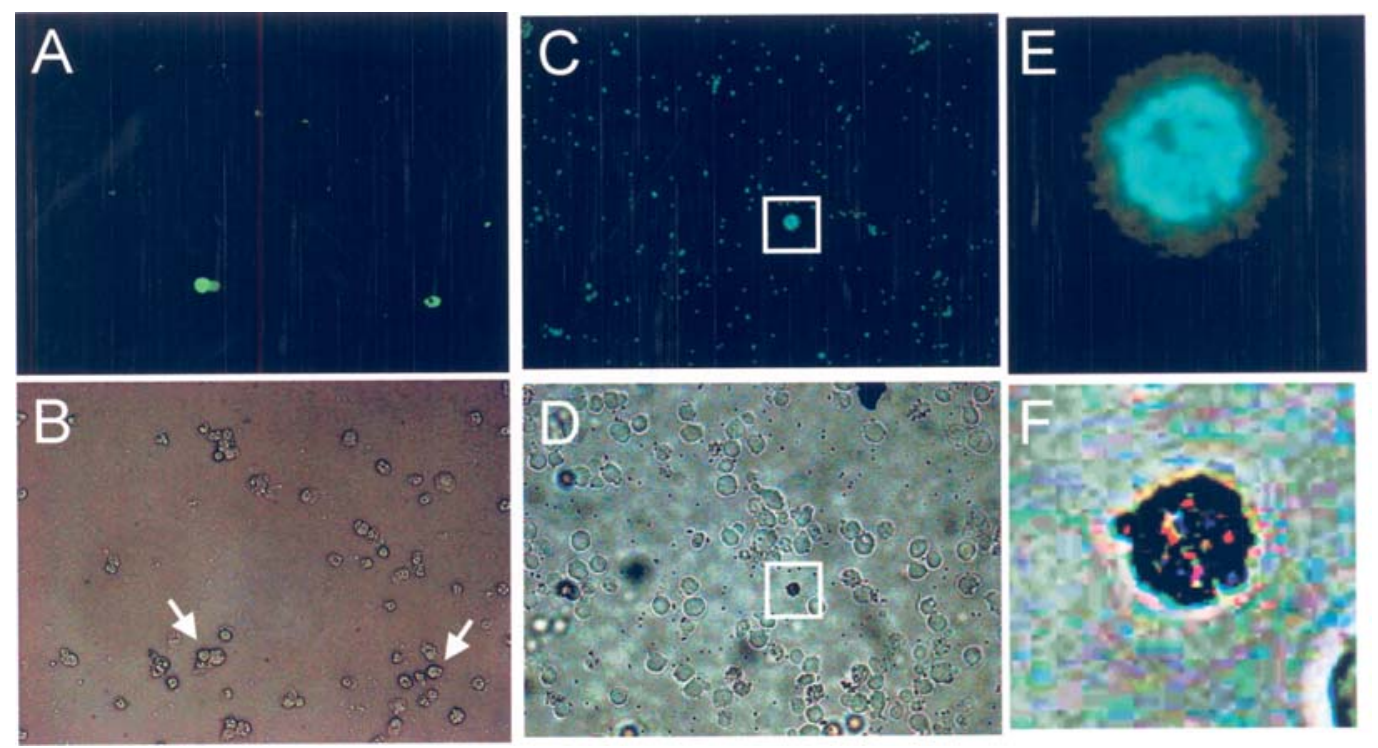

Figure 4. Identification of $\gamma$-globin-containing (A,B) and MEM-G9-positive (C-F) cells. Staining with fluorescent anti- $\gamma$-globin antibodies is a strategy to identify fNRBC (18); binding of MEM-G9-loaded fluorescent microspheres are currently employed to detect HLA-G-positive trophoblasts. A and C, microscopic analysis; $\mathrm{B}$ and $\mathrm{D}$, fluorescence analysis. $\mathrm{E}$ and $\mathrm{F}$ are enlargements of panels $\mathrm{C}$ and $\mathrm{D}$ (the enlarged region is identified by a box).

the particle may experience a force that will direct it away from high electric field strength regions (this phenomenon is called nDEP).

The general set-up of a DEP-based system is shown in Fig. 2A, and is generally constituted by a microscope (Fig. 2A), connected with CDD-camera and computer (Fig. 2A and $\mathrm{E}$ ), and platforms suitable for inclusion of the Lab-on-achip devices (Fig. 2C). Several DEP-based Lab-on-a-chip devices were recently described and found to be suitable for biotechnological applications in the field of isolation of singlecell population as well as manipulation of single biological objects, including cells and microspheres.

\section{DEP-based Lab-on-a-chip devices with high-density arrayed electrodes}

Fig. 3A and B shows the DEP-array, which is constituted by a microchamber defined by the chip surface and a conductive- 

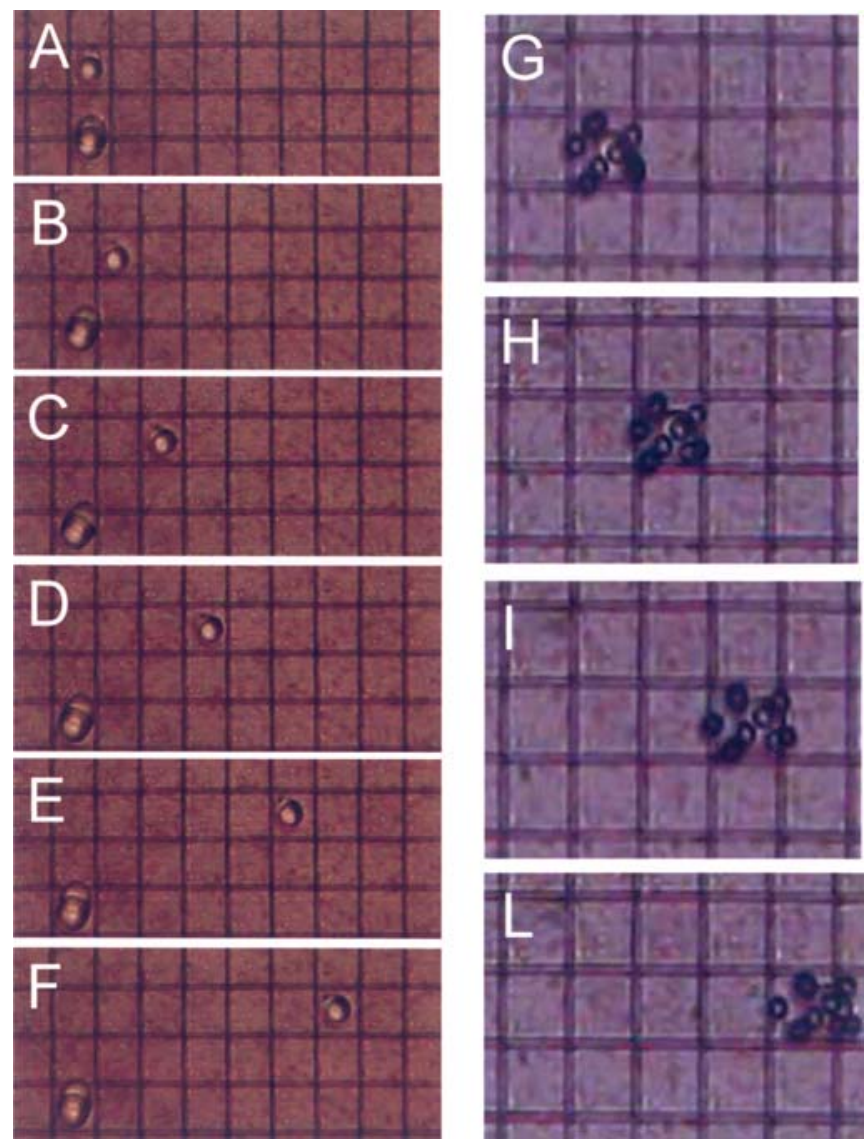

Figure 5. Routing of a single cell (A-F) or a cell-microsphere complex (G-L). Photographs were taken at the beginning $(\mathrm{A}, \mathrm{G})$ or after $30 \mathrm{sec}(\mathrm{B}, \mathrm{H}), 1 \mathrm{~min}$ (C and I), $90 \mathrm{sec}(\mathrm{D}$ and $\mathrm{L}), 2 \mathrm{~min}(\mathrm{E})$ and $2.5 \mathrm{~min}(\mathrm{~F})$. These data are taken from Borgatti et al (91). glass lid. The chip surface implements a two-dimensional array of 320x320 microsites, each consisting of a superficial electrode, embedded sensors and logic. The electrode array is implemented with CMOS (complementary metal oxyde semiconductor) top-metal and protected from the liquid by the standard CMOS passivation. The design, technical parameters, building approach and manufacture of this DEP-based arrayed device have been described by Medoro et al (84-86) and Manaresi et al (87). In this system, a closed DEP-cage in the spatial region above a microsite can be created by connecting the associated electrode and the microchamber lid to a counterphase sinusoidal voltage, while the electrode of the neighboring microsites is connected to an in-phase sinusoidal voltage. A minimum field is thus created in the liquid, corresponding to a DEP-cage in which, depending on its size, one or more particles can be trapped and levitated. This system allows the creation of 4,000-10,000 DEP-cages, able to entrap single cells or cell-microsphere complexes $(85,86)$. By changing, under software control, the pattern of voltages applied to the electrodes, these spherical DEP-cages can be independently moved around the device plane (Fig. 3C), thus grabbing and dragging cells and/or microbeads across the chip. Particles in the sample can be detected by the changes in optical radiation impinging on the photodiode associated with each microsite. Thanks to the small pitch of the electrodes, single cells can be individually trapped in separate cages (insert, Fig. 3B) and independently moved on the device (Fig. 3C and in the representative experiments depicted in Fig. 3D and E). Particle position is digitally controlled step-by-step in a deterministic way, by applying a corresponding pattern of voltages to the array which set the position of the DEP-cages.

The most important features of the Lab-on-a-chip device are: a) it carries out functions of both actuating and sensing

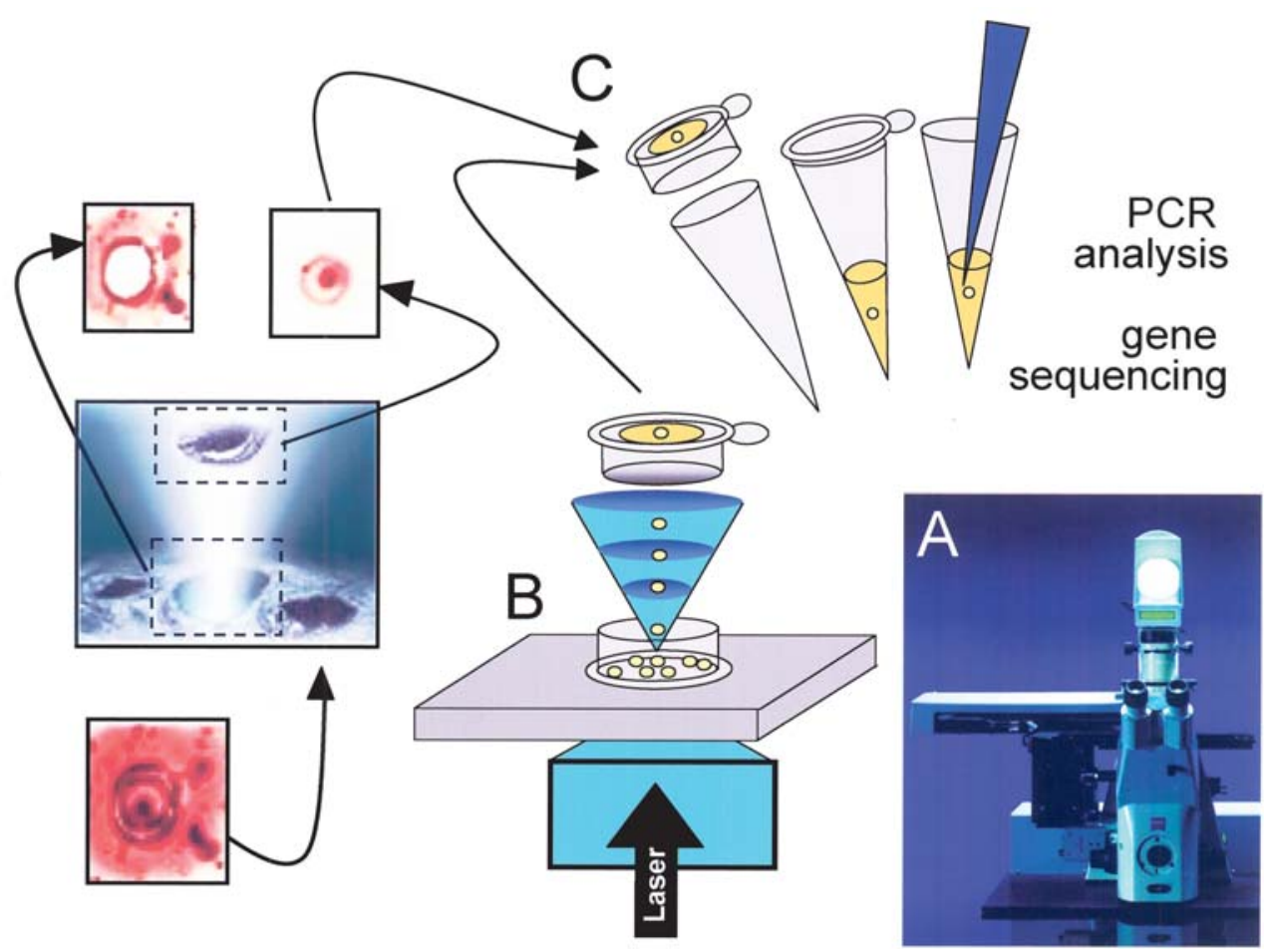

Figure 6. Scheme outlining the Leica PALM MicroBean system; (A) the instrument and (B) the concept of laser pressure catapulting. After catapulting, the isolated cells can be recovered for molecular diagnosis (C). 
type, b) the DEP-chip is optimal for the separation of large numbers of eukaryotic cells; c) the DEP-array can be programmed for moving single cells; and d) single cells can be forced to contact antibody-exposing microspheres.

In respect to isolation of a pure cell population, additional published results (reviewed in ref. 84) have firmly demonstrated that human cell populations of different histotype and differentiation stage are able to be isolated using DEP-based devices. These features propose Lab-on-a-chip platforms for diagnostic applications, cell separation and characterization in the field of non-invasive prenatal diagnosis (88-98).

First, in order to follow the step indicated in Fig. 1C and $\mathrm{D}$, it is crucial to demonstrate that interaction between antibodies and surface antigens is stable in buffers employed for DEP. This is shown in Fig. 4A and B, showing staining of $\gamma$-globin-expressing cells (expressed by fNRBC) in $280 \mathrm{mM}$ mannitol and $6.25 \mathrm{mM} \mathrm{KCl}$, a buffer commonly used in DEP experiments. In addition, cells can be labeled with fluorescence beads carrying specific antibodies. In Fig. 4C-F a single HLA-G-expressing cell is identified in $280 \mathrm{mM}$ mannitol/6.25 $\mathrm{mM} \mathrm{KCl}$ from the other negative cells by using the MoAb MEM-G9, specific for trophoblasts.

Secondly, after identification of single cells or cellmicrosphere complexes, these can be forced to move to preidentified areas of the Lab-on-a-chip device. This is demonstrated in the representative experiment shown in Fig. 5, in which a single cell (A-F) or a single-cell microsphere complex (G-L) are moved along the chip, allowing the concentration of the identified cells to recovery places of the device, as indicated by panels D and E of Fig. 3.

The data presented here and those available in the literature indicate that the dielectrophoresis (DEP)-based Lab-on-achip approach meets the required criteria for the optimization of enrichment of fetal cells in the blood of pregnant women for non-invasive prenatal diagnosis.

\section{Competing technologies: Noncontact laser micro- dissection and pressure catapulting (LMPC) for isolation of single cells}

In recent years, laser microdissection and pressure catapulting (LMPC) has been described as an emerging technology for the isolation of identified cells for genomic analysis (99-101). This approach enables pure and homogeneous sample preparation $(102,103)$. For microdissection, the force of focused laser light is used to excise selected cells or large tissue areas from object slides or from living cell cultures down to a resolution of individual single cells and subcellular components like organelles or chromosomes, respectively (Fig. 6A and B). After microdissection this sample is directly catapulted into an appropriate collection device (Fig. 6B). As the entire process is conducted without any mechanical contact, it enables pure sample retrieval from a morphologically defined origin without cross-contamination. Wherever homogenous samples are required for subsequent analysis of, e.g. cell areas, single cells, or chromosomes, the PALM MicroBeam system is an indispensable tool. The integration of image analysis platforms fully automates screening, identification, and finally subsequent highthroughput sample handling. These samples can be directly linked into versatile downstream applications, such as singlecell mRNA extraction, different PCR methods, microarray techniques, and various others (Fig. 6C).

\section{Conclusions}

The optimization of prenatal diagnosis for chromosomal and monogenic disorders can be greatly facilitated if obtaining fetal material from maternal blood is efficiently and reproducibly obtained, avoiding the risks associated with amniocentesis, chorionic villus sampling and fetal blood sampling.

The isolation of rare cells from maternal blood for noninvasive prenatal diagnosis is a new field of research exhibiting several difficulties since this strategy requires several basic technological protocols for a successful outcome $(19,45,46,48$, $50,52,62,68,104-112)$.

Risk factors for DEP-based Lab-on-a-chip development are as follows. i) Antigen-antibody interactions in the DEP buffers. The binding between monoclonal antibodies and target cells occurs in mannitol-based buffers. However, the present published data do not support the hypothesis that for all the monoclonal antibodies necessary for fetal cell identification in non-invasive prenatal diagnosis, the efficiency in DEP buffer is the same of binding reactions performed in RPMI. ii) Isolation of cells after DEP-based Lab-on-a-chip separation. The isolation of cells from the DEP-array, despite not being optimized and published so far, is expected to be developed for FACS/MACS and Lab-on-a-chip enrichment of fetal cells from maternal blood. iii) Vitality of the cells after DEPmanipulation and Lab-on-a-chip separation. This point is not crucial for DNA-based diagnosis (performance of PCR, microsequencing, allele discrimination); however, it might be of great interest for chromosomal analysis. The collective data suggest that no mutations are introduced by DEP treatment, and cells can be viable after DEP separation.

\section{Acknowledgements}

This study was supported by MURST-COFIN-2002 (applications of a dielectrophoresis-based Lab-on-a-chip for diagnosis and drug research and development) and by FIRB2001 (development of a Lab-on-a-chip based on microelectronic technologies and its biotechnological validation). This research was also supported by Fondazione Italiana Ricerca sulla Fibrosi Cistica, by AIRC, by Associazione Veneta per la Lotta alla Talassemia, Rovigo and by Fondazione Cassa di Risparmio di Padova e Rovigo. We thank Silicon Biosystems (Bologna) for the technical support.

\section{References}

1. Wapner RJ: Invasive prenatal diagnostic techniques. Semin Perinatol 29: 401-404, 2005.

2. Chen CP, Lin CC, Li YC, Chern SR, Lee CC, Chen WL, Lee MS, Wang W and Tzen CY: Clinical, cytogenetic, and molecular analyses of prenatally diagnosed mosaic tetrasomy for distal chromosome $15 \mathrm{q}$ and review of the literature. Prenat Diagn 24: 767-773, 2004.

3. Seeds JW: Diagnostic mid-trimester amniocentesis: how safe? Am J Obstet Gynecol 191: 607-615, 2004.

4. Ball RH: Invasive fetal testing. Curr Opin Obstet Gynecol 16: 159-162, 2004. 
5. Jackson L and Wapner RJ: Chorionic villus sampling. In: Essentials of Prenatal Diagnosis. Simpson JL and Elias S (eds). Churchill Livingstone, New York, pp45-61, 1993.

6. Christensen B, Philip J, Kolvraa S, Lykke-Hansen L, Hromadnikova I, Gohel D, Lorch T, Plesch A, Bang J, Smidt-Jensen S, Hertz J and Djursing H: Fetal cells in maternal blood: a comparison of methods for cell isolation and identification. Fetal Diagn Ther 20: 106-112, 2005.

7. Papasavva T, Kalakoutis G, Kalikas I, Neokli E, Papacharalambous S, Kyrri A and Kleanthous M: Noninvasive prenatal diagnostic assay for the detection of beta-thalassemia. Ann NY Acad Sci 1075: 148-153, 2006.

8. Galbiati S, Restagno G, Foglieni B, Bonalumi S, Travi M, Piga A, Sbaiz L, Chiari M, Damin F, Smid M, Valsecchi L, Pasi F, Ferrari A, Ferrari M and Cremonesi L: Different approaches for noninvasive prenatal diagnosis of genetic diseases based on PNA-mediated enriched PCR. Ann NY Acad Sci 1075: 137-143, 2006.

9. Uitto J, Pfendner E and Jackson LG: Probing the fetal genome: progress in non-invasive prenatal diagnosis. Trends Mol Med 9: 339-343, 2003.

10. Avent ND and Chitty LS: Non-invasive diagnosis of fetal sex; utilisation of free fetal DNA in maternal plasma and ultrasound. Prenat Diagn 26: 598-603, 2006.

11. Tong YK and Lo YM: Diagnostic developments involving cellfree (circulating) nucleic acids. Clin Chim Acta 363: 187-196, 2006.

12. Li Y, Page-Christiaens GC, Gille JJ, Holzgreve W and Hahn S: Non-invasive prenatal detection of achondroplasia in sizefractionated cell-free DNA by MALDI-TOF MS assay. Prenat Diagn 27: 11-17, 2007

13. Dennis Lo YM and Chiu RW: Prenatal diagnosis: progress through plasma nucleic acids. Nat Rev Genet 8: 71-77, 2007.

14. van Wijk IJ, de Hoon AC, Griffioen S, Mulders MA, Tjoa ML, van Vugt JM and Oudejans CB: Identification of triploid trophoblast cells in peripheral blood of a woman with a partial hydatidiform molar pregnancy. Prenat Diagn 21: 1142-1145, 2001.

15. van Wijk IJ, Griffioen S, Tjoa ML, Mulders MA, van Vugt JM, Loke YW and Oudejans CB: HLA-G expression in trophoblast cells circulating in maternal peripheral blood during early pregnancy. Am J Obstet Gynecol 184: 991-997, 2001.

16. Schueler PA, Yamanishi DT, Pearson J, Lee Y, Wu X, Hashima S, Madlansacay MR, Cain CA, Collarini EJ, Foltz L and Mahoney W: Inconsistency of fetal trophoblast cells in first trimester maternal peripheral blood prevents non-invasive fetal testing using this cell target. Placenta 22: 702-715, 2001.

17. Mavrou A, Kolialexi A, Antsaklis A, Korantzis A and Metaxotou C: Identification of fetal nucleated red blood cells in the maternal circulation during pregnancy using antihemoglobin-epsilon antibody. Fetal Diagn Ther 18: 309-313, 2003.

18. Guetta E, Simchen MJ, Mammon-Daviko K, Gordon D, Aviram-Goldring A, Rauchbach N and Barkai G: Analysis of fetal blood cells in the maternal circulation: challenges, ongoing efforts, and potential solutions. Stem Cells Dev 13: 93-99, 2004.

19. Troeger C, Holzgreve W and Hahn S: A comparison of different density gradients and antibodies for enrichment of fetal erythroblasts by MACS. Prenat Diagn 19: 521-526, 1999.

20. Krabchi K, Gadji M, Samassekou O, Gregoire MC, Forest JC and Drouin R: Quantification of fetal nucleated cells in maternal blood of pregnant women with a male trisomy 21 fetus using molecular cytogenetic techniques. Prenat Diagn 26: 28-34, 2006.

21. Torricelli F and Pescucci C: Isolation of fetal cells from the maternal circulation: prospects for the non-invasive prenatal diagnosis. Clin Chem Lab Med 39: 494-500, 2001.

22. Ho SS, O'Donoghue K and Choolani M: Fetal cells in maternal blood: state of the art for non-invasive prenatal diagnosis. Ann Acad Med Singapore 32: 597-603, 2003.

23. Walknowska J, Conte FA and Grumbach MM: Practical and theoretical implication of fetal:maternal lymphocyte transfer. Lancet 1: 1119-1122, 1969.

24. Herzenberg LA, Bianchi DW, Schroder J, Cann HM and Iverson GM: Fetal cells in the blood of pregnant women: detection and enrichment by fluorescence-activated cell sorting. Proc Nat Acad Sci USA 76: 1453-1455, 1979.

25. Schmorl G: Pathologisch-Anatomische Untersuchungen uber Puerperal Eklampsie. Leipzig, Vogel, 1893.
26. Hahnemann JM and Vejerslev LO: Accuracy of cytogenetic findings on chorionic villus sampling (CVS)-diagnostic consequences of CVS mosaicism and non-mosaic discrepancy in centres contributing to EUCROMIC 1986-1992. Prenat Diagn 17: 801-820, 1997.

27. Bianchi DW, Flint AF, Pizzimenti MF, Knoll JHM and Latt SA: Isolation of fetal DNA from nucleated erythrocytes in maternal blood. Proc Nat Acad Sci USA 87: 3279-3283, 1990.

28. Price JO, Elias S, Wachtel SS, Klinger K, Dockter M, Tharapel A, Shulman LP, Phillips OP, Meyers CM, Shook D, et al: Prenatal diagnosis with fetal cells isolated from maternal blood by multiparameter flow cytometry. Am J Obstet Gynecol 165: 1731-1737, 1991.

29. Ganshirt D, Smeets FW, Dohr A, Walde C, Steen I, Lapucci C, Falcinelli C, Sant R, Velasco M, Garritsen HS and Holzgreve W: Enrichment of fetal nucleated red blood cells from the maternal circulation for prenatal diagnosis: experiences with triple density gradient and MACS based on more than 600 cases. Fetal Diagn Therap 13: 276-286, 1998.

30. Bischoff FZ, Marquez-Do DA, Martinez DI, Dang D, Horne C, Lewis D and Simpson JL: Intact fetal cell isolation from maternal blood: improved isolation using a simple whole blood progenitor cell enrichment approach (RosetteSep). Clin Genet 63: 483-489, 2003.

31. Wachtel SS, Sammons D, Manley M, Wachtel G, Twitty G, Utermohlen J, Phillips OP, Shulman LP, Taron DJ, Muller UR, Koeppen P, Ruffalo TM, Addis K, Porreco R, Murata-Collins J, Parker NB and McGavran L: Fetal cells in maternal blood: recovery by charge flow separation. Hum Genet 98: 162-166, 1996.

32. von Eggeling F, Michel S, Gunther M, Schimmel B and Claussen U: Determination of the origin of single nucleated cells in maternal circulation by means of random PCR and a set of length polymorphisms. Hum Genet 99: 266-270, 1997.

33. Samura O, Sohda S, Johnson KL, Pertl B, Ralston S, Delli-Bovi LC, et al: Diagnosis of trisomy 21 in fetal nucleated erythrocytes from maternal blood by use of short tandem repeat sequences. Clin Chem 47: 1622-1626, 2001.

34. Cheung MC, Goldberg JD and Kan YW: Prenatal diagnosis of sickle cell anaemia and thalassaemia by analysis of fetal cells in maternal blood. Nat Genet 14: 264-268, 1996.

35. Suzumori K, Adachi R, Okada S, Narukawa T, Yagami Y and Sonta S: Fetal cells in the maternal circulation: detection of $Y-$ sequence by gene amplification. Obstet Gynecol 80: 150-154, 1992.

36. Sekizawa A, Kimura T, Sasaki M, Nakamura S, Kobayashi R and Sato T: Prenatal diagnosis of Duchenne muscular dystrophy using a single fetal nucleated erythrocyte in maternal blood. Neurology 46: 1350-1353, 1996.

37. Ganshirt-Ahlert D, Borjesson-Stoll R, Burschyk M, Dohr A, Garritsen HS, Helmer E, et al: Detection of fetal trisomies 21 and 18 from maternal blood using triple gradient and magnetic cell sorting. Am J Reprod Immunol 30: 194-201, 1993.

38. Cacheux V, Milesi-Fluet C, Tachdjian G, Druart L, Bruch JF, Hsi BL, Uzan S and Nessmann C: Detection of 47,XYY trophoblast fetal cells in maternal blood by fluorescence in situ hybridization after using immunomagnetic lymphocyte depletion and flow cytometry sorting. Fetal Diagn Ther 7: 190-194, 1992.

39. Pezzolo A, Santi F, Pistoia V and De Biasio P: Prenatal diagnosis of triploidy using fetal cells in the maternal circulation. Prenat Diagn 17: 389, 1997.

40. Geifman-Holtzman O, Bernstein IM, Berry SM, Holtzman EJ, Vadnais TJ, DeMaria MA and Bianchi DW: Fetal Rh genotyping in fetal cells flow sorted from maternal blood. Am J Obstet Gynecol 174: 818-822, 1996.

41. Oosterwijk JC, Mesker WE, Ouwerkerk-van Velzen MC, Knepfle CF, Wiesmeijer KC, Beverstock GC, Van Ommen GJ, Tanke HJ and Kanhai HH: Prenatal diagnosis of trisomy 13 on fetal cells obtained from maternal blood after minor enrichment. Prenat Diagn 18: 1082-1085, 1998.

42. de Graf IM, van Bezouw SM, Jakobs ME, Leschot NJ, Zondervan HA, Bilardo CM and Hoovers JM: First trimester non-invasive prenatal diagnosis of triploidy. Prenat Diagn 19: 175-177, 1999.

43. Choolani M, O'Donnell H, Campagnoli C, Kumar S, Roberts I, Bennett PR and Fisk NM: Simultaneous fetal cell identification and diagnosis by epsilon globin chain immunophenotyping and chromosomal fluorescence in situ hybridization. Blood 98 : 554-557, 2001. 
44. Winichagoon P, Sithongdee S, Kanokpongsakdi S, Tantisirin P, Bernini LF and Fucharoen S: Noninvasive prenatal diagnosis for hemoglobin Bart's hydrops fetalis. Int J Hematol 81: 396-399, 2005.

45. Nagy GR, Ban Z, Sipos F, Beke A, Papp C and Papp Z: Isolation of epsilon-haemoglobin-chain positive fetal cells with micromanipulation for prenatal diagnosis. Prenat Diagn 25: 398-402, 2005.

46. Fernandez A, Prieto B, Escudero A, Ladenson JH and Alvarez FV: A monoclonal antibody with potential for aiding non-invasive prenatal diagnosis: utility in screening of pregnant women at risk of preeclampsia. J Histochem Cytochem 53: 345-350, 2005.

47. Al-Mufti R, Hambley H, Farzaneh F and Nicolaides KH: Fetal and embryonic hemoglobins in erythroblasts from fetal blood and fetal cells enriched from maternal blood in pregnancies complicated by maternal diabetes mellitus. J Matern Fetal Neonatal Med 15: 109-114, 2004.

48. Al-Mufti R, Hambley H, Farzaneh F and Nicolaides KH: Assessment of efficacy of cell separation techniques used in the enrichment of foetal erythroblasts from maternal blood: triple density gradient vs. single density gradient. Clin Lab Haematol 26: 123-128, 2004.

49. Christensen B, Philip J, Lykke-Hansen L and Kolvraa S: Sensitivity and specificity of the identification of fetal cells in maternal blood by combined staining with antibodies against beta-, gamma- and epsilon-globin chains. Fetal Diagn Ther 18: 479-484, 2003

50. Christensen B, Kolvraa S, Lykke-Hansen L, Lorch T, Gohel D, Smidt-Jensen S, Bang J and Philip J: Studies on the isolation and identification of fetal nucleated red blood cells in the circulation of pregnant women before and after chorion villus sampling. Fetal Diagn Ther 18: 376-384, 2003.

51. Choi JW, Kim Y, Fujino M and Ito M: Significance of fetal hemoglobin-containing erythroblasts (F blasts) and the $\mathrm{F}$ blast/F cell ratio in myelodysplastic syndromes. Leukemia 16: 1478-1483, 2002.

52. Collarini EJ, Nagy D, Cain CA, Gammon D, Schueler PA and Mahoney WC: A novel method for depositing erythroid cells onto glass slides for fetal cell analysis. Cytometry 45: 304-309, 2001 .

53. Collarini EJ, Cain CA, Gammon D, Harriman B, Magee K, Du G, Schueler PA and Mahoney WC: Comparison of methods for erythroblast selection: application to selecting fetal erythroblasts from maternal blood. Cytometry 45: 267-276, 2001.

54. Xu H, Foltz L, Sha Y, Madlansacay MR, Cain C, Lindemann G, Vargas J, Nagy D, Harriman B, Mahoney W and Schueler PA: Cloning and characterization of human erythroid membraneassociated protein, human ERMAP. Genomics 76: 2-4, 2001

55. Martel-Petit V, Petit C, Marchand M, Fleurentin A, Fontaine B, Miton A, Lemarie P, Philippe C and Jonveaux P: Use of the Kleihauer test to detect fetal erythroblasts in the maternal circulation. Prenat Diagn 21: 106-111, 2001.

56. Sekizawa A, Samura O, Zhen DK, Falco V, Farina A and Bianchi DW: Apoptosis in fetal nucleated erythrocytes circulating in maternal blood. Prenat Diagn 20: 886-889, 2000 .

57. Jakobs ME, van Lith JM, de Graaf IM, Knegt AC and Hoovers JM: Genetic analysis of fetal nucleated red blood cells from CVS washings. Prenat Diagn 20: 832-834, 2000.

58. Samura O, Pertl B, Sohda S, Johnson KL, Sekizawa A, Falco VM, Elmes RS and Bianchi DW: Female fetal cells in maternal blood: use of DNA polymorphisms to prove origin. Hum Genet 107: 28-32, 2000

59. Al-Mufti R, Hambley H, Farzaneh F and Nicolaides KH: Fetal and embryonic hemoglobins in erythroblasts of chromosomally normal and abnormal fetuses at 10-40 weeks of gestation. Haematologica 85: 690-693, 2000. Erratum in: Haematologica 85: 869,2000

60. Al-Mufti R, Hambley H, Albaiges G, Lees C and Nicolaides KH: Increased fetal erythroblasts in women who subsequently develop pre-eclampsia. Hum Reprod 15: 1624-1628, 2000.

61. Di Naro E, Ghezzi F, Vitucci A, Tannoia N, Campanale D, D'Addario V, Holzgreve W and Hahn S: Prenatal diagnosis of beta-thalassaemia using fetal erythroblasts enriched from maternal blood by a novel gradient. Mol Hum Reprod 6: 571-574, 2000.

62. Sekizawa A, Samura O, Zhen DK, Falco V and Bianchi DW: Fetal cell recycling: diagnosis of gender and $\mathrm{RhD}$ genotype in the same fetal cell retrieved from maternal blood. Am J Obstet Gynecol 181: 1237-1242, 1999.
63. Cunningham J, Yates Z, Hamlington J, Mason G, Mueller R and Miller D: Non-invasive RNA-based determination of fetal Rhesus D type: a prospective study based on 96 pregnancies. $\mathrm{Br}$ J Obstet Gynaecol 106: 1023-1028, 1999.

64. Sekizawa A, Farina A, Zhen DK, Wang JY, Falco VM, Elmes S and Bianchi DW: Improvement of fetal cell recovery from maternal blood: suitable density gradient for FACS separation. Fetal Diagn Ther 14: 229-233, 1999.

65. Wang Z and Liebhaber SA: A 3'-flanking NF-kappaB site mediates developmental silencing of the human zeta-globin gene. EMBO J 18: 2218-2228, 1999.

66. Furusawa T, Yanai N, Hara T, Miyajima A and Obinata M: Integrin-associated protein (IAP, also termed CD47) is involved in stroma-supported erythropoiesis. J Biochem 123: 101-106, 1998

67. Pezzolo A, Santi F, Pistoia V and De Biasio P: Prenatal diagnosis of triploidy and trisomy 21 through fetal erythroblasts isolated from maternal blood. Minerva Med 88: 393-399, 1997.

68. Navenot JM, Muller JY and Blanchard D: Expression of blood group $\mathrm{i}$ antigen and fetal hemoglobin in paroxysmal nocturnal hemoglobinuria. Transfusion 37: 291-297, 1997.

69. Savion S, Carp H, Shepshelovich J, Irlin J, Kostykov M, Fein A and Toder V: Use of antibodies against the human antigen of erythroblasts for the detection of nucleated erythrocytes in the maternal circulation. Biol Neonate 71: 126-130, 1997.

70. Kazama A, Mano H, Morishita Y and Mori S: High expression of the tec gene product in murine testicular germ cells and erythroblasts. Pathol Int 46: 341-347, 1996.

71. Ziegler BL, Lamping CP, Thoma SJ and Fliedner TM: Analysis of gene expression in small numbers of purified hemopoietic progenitor cells by RT-PCR. Stem Cells 13 (suppl 1): 106-116, 1995

72. Guetta E, Gutstein-Abo L and Barkai G: Trophoblasts isolated from the maternal circulation: in vitro expansion and potential application in non-invasive prenatal diagnosis. J Histochem Cytochem 53: 337-339, 2005

73. Mavrou A, Colialexi A, Tsangaris GT, Antsaklis A, Panagiotopoulou P, Tsenghi C and Metaxotoy C: Fetal cells in maternal blood: isolation by magnetic cell sorting and confirmation by immunophenotyping and FISH. In Vivo 12: 195-200, 1998.

74. Jansen MW, von Lindern M, Beug H, Brandenburg H, Wildschut HI, Wladimiroff JW and In't Veld PA: The use of in vitro expanded erythroid cells in a model system for the isolation of fetal cells from maternal blood. Prenat Diagn 19: 323-329, 1999.

75. Prieto B, Candenas M, Ladenson $\mathrm{JH}$ and Alvarez FV: Comparison of different CD71 monoclonal antibodies for enrichment of fetal cells from maternal blood. Clin Chem Lab Med 40: 126-131, 2002

76. Gambari R, Borgatti M, Altomare L, Manaresi N, Medoro G, Romani A, Tartagni M and Guerrieri R: Applications to cancer research of 'lab-on-a-chip' devices based on dielectrophoresis (DEP). Technol Cancer Res Treat 2: 31-40, 2003.

77. Pohl HA and Crane JS: Dielectrophoretic force. J Theor Biol 37: 1-13, 1972.

78. Crane JS and Pohl HA: Theoretical models of cellular dielectrophoresis. J Theor Biol 37, 15-41, 1972.

79. Voldman J, Braff RA, Toner M, Gray ML and Schmidt MA Holding forces of single-particle dielectrophoretic traps Biophys J 80: 531-541, 2001.

80. Gascoyne PR and Vykoukal J: Particle separation by dielectrophoresis. Electrophoresis 23: 1973-1983, 2002.

81. Fiedler S, Shirley SG, Schnelle T and Fuhr G: Dielectrophoretic sorting of particles and cells in a microsystem. Anal Chem 70: 1909-1915, 1998

82. Morgan H, Hughes MP and Green NG: Separation of submicron bioparticles by dielectrophoresis. Biophys J 77: 516-525, 1999.

83. Altomare L, Borgatti M, Medoro G, Manaresi N, Tartagni M, Guerrieri R and Gambari R. Levitation and movement of human tumor cells using a printed circuit board device based on software-controlled dielectrophoresis. Biotechnol Bioeng 82: 474-479, 2003

84. Medoro G, Manaresi N, Tartagni M and Guerrieri R: CMOSonly sensor and manipulation for micro-organisms. Proceedings IEDM 415-418, 2000 .

85. Medoro G, Manaresi N, Leonardi A, Altomare L, Tartagni M and Guerrieri R: A 'Lab-on-a-chip' for cell detection and manipulation. Proceedings IEEE Sensors Conference, June, 2002 . 
86. Medoro G, Manaresi N, Tartagni M, Altomare L, Leonardi A and Guerrieri R: A 'Lab-on-a-chip' for cell separation based on the moving-cage approach. Eurosensors, September, 2002.

87. Manaresi N, Romani A, Medoro G, Altomare L, Leonardi A, Tartagni M and Guerrieri R: A CMOS Chip for individual cell manipulation and detection. IEEE J Solid-State Circuits 38: 2297-2304, 2003.

88. Huang Y, Yang J, Wang XB, Becker FF and Gascoyne PR: The removal of human breast cancer cells from hematopoietic $\mathrm{CD} 34^{+}$stem cells by dielectrophoretic field-flow-fractionation. J Hematother Stem Cell Res 8: 481-490, 1999.

89. Yang J, Huang Y, Wang XB, Becker FF and Gascoyne PR: Differential analysis of human leukocytes by dielectrophoretic field-flow-fractionation. Biophys J 78: 2680-2689, 2000.

90. Wang XB, Yang J, Huang Y, Vykoukal J, Becker FF and Gascoyne PR: Cell separation by dielectrophoretic field-flowfractionation. Anal Chem 72: 832-839, 2000.

91. Borgatti M, Manaresi N, Medoro G, Mancini I, Fabbri E, Guerrieri R and Gambari R: Dielectrophoresis based Lab-on-achip platforms for the identification and manipulation of rare cells and microspheres: implications for non-invasive prenatal diagnosis. Minerva Biotecnologica 19: 43-49, 2007.

92. Huang Y, Joo S, Duhon M, Heller M, Wallace B and Xu X: Dielectrophoretic cell separation and gene expression profiling on microelectronic chip arrays. Anal Chem 74: 3362-3371, 2002.

93. Cheng J, Sheldon EL, Wu L, Heller MJ and O'Connell JP: Isolation of cultured cervical carcinoma cells mixed with peripheral blood cells on a bioelectronic chip. Anal Chem 70: 2321-2326, 1998 .

94. Xu C, Wang Y, Cao M and Lu Z: Dielectrophoresis of human red cells in microchips. Electrophoresis 20: 1829-1831, 1999.

95. Yu Z, Xiang G, Pan L, Huang L, Yu Z, Xing W and Cheng J: Negative dielectrophoretic force assisted construction of ordered neuronal networks on cell positioning bioelectronic chips. Biomed Microdevices 6: 311-324, 2004.

96. Borgatti M, Altomare L, Baruffa M, Fabbri E, Breveglieri G, Feriotto G, Manaresi N, Medoro G, Romani A, Tartagni M, Gambari R and Guerrieri R: Separation of white blood cells from erythrocytes on a dielectrophoresis (DEP) based 'Lab-ona-chip' device. Int J Mol Med 15: 913-920, 2005.

97. Borgatti M, Altomare L, Abonnec M, Fabbri E, Manaresi N, Medoro G, Romani A, Tartagni M, Nastruzzi C, Di Croce S, Tosi A, Mancini I, Guerrieri R and Gambari R: Dielectrophoresis (DEP) based 'Lab-on-a-chip' devices for efficient and programmable binding of microspheres to target cells. Int J Oncol 27: 1559-1566, 2005.

98. Gambari R, Borgatti M, Fabbri E, Gavioli R, Fortini C, Nastruzzi C, Altomare L, Abonnenc M, Manaresi N, Medoro G, Romani A, Tartagni M and Guerrieri R: 'Lab-on-a-chip' devices for cellular arrays based on dielectrophoresis (DEP). In: Bioarrays, from Basics to Diagnostics. Appasani K (ed). Humana Press, New Jersey, pp231-243, 2007.

99. Burgemeister R: New aspects of laser microdissection in research and routine. J Histochem Cytochem 53: 409-412, 2005.
100. Kuhn DE, Roy S, Radtke J, Gupta S and Sen CK: Laser microdissection and pressure-catapulting technique to study gene expression in the reoxygenated myocardium. Am J Physiol Heart Circ Physiol 290: H2625-H2632, 2006.

101. Chaudhary KW, Barrezueta NX, Bauchmann MB, Milici AJ, Beckius G, Stedman DB, Hambor JE, Blake WL, McNeish JD, Bahinski A and Cezar GG: Embryonic stem cells in predictive cardiotoxicity: laser capture microscopy enables assay development. Toxicol Sci 90: 149-158, 2006.

102. Niyaz Y, Stich M, Sagmuller B, Burgemeister R, Friedemann G, Sauer U, Gangnus R and Schutze K: Noncontact laser microdissection and pressure catapulting: sample preparation for genomic, transcriptomic, and proteomic analysis. Methods Mol Med 114: 1-24, 2005

103.Langer S, Geigl JB, Ehnle S, Gangnus R and Speicher MR: Live cell catapulting and recultivation does not change the karyotype of HCT116 tumor cells. Cancer Genet Cytogenet 161: 174-177, 2005.

104. Sitar G, Garagna S, Zuccotti M, Falcinelli C, Montanari L, Alfei A, Ippoliti G, Redi CA, Moratti R, Ascari E and Forabosco A: Fetal erythroblast isolation up to purity from cord blood and their culture in vitro. Cytometry 35: 337-345, 1999.

105.Zheng YL, Zhen DK, DeMaria MA, Berry SM, Wapner RJ, Evans MI, Copeland D, Williams JM and Bianchi DW: Search for the optimal fetal cell antibody: results of immunophenotyping studies using flow cytometry. Hum Genet 100: 35-42, 1997.

106. Irene Jauho E and Havsteen Jakobsen M: Rare cell isolation using antibodies covalently linked to slides: application to fetal cells in maternal blood. Prenat Diagn 23: 898-900, 2003.

107. Cirigliano V, Voglino G and Adinolfi M: Non-invasive screening and rapid QF-PCR assay can greatly reduce the need for conventional cytogenetic analyses in prenatal diagnosis. Reprod Biomed Online 11: 671-673, 2005.

108. Ogilvie CM, Donaghue C, Fox SP, Docherty Z and Mann K: Rapid prenatal diagnosis of aneuploidy using quantitative fluorescence-PCR (QF-PCR). J Histochem Cytochem 53: 285-288, 2005.

109. Donaghue C, Mann K, Docherty Z and Ogilvie CM: Detection of mosaicism for primary trisomies in prenatal samples by QFPCR and karyotype analysis. Prenat Diagn 25: 65-72, 2005.

110.El Mouatassim S, Becker M, Kuzio S, Ronsin C, Gil S, Nouchy M, Druard L and Forestier F: Prenatal diagnosis of common aneuploidies using multiplex quantitative fluorescent polymerase chain reaction. Fetal Diagn Ther 19: 496-503, 2004.

111. Mann K, Donaghue C, Fox SP, Docherty Z and Ogilvie CM: Strategies for the rapid prenatal diagnosis of chromosome aneuploidy. Eur J Hum Genet 12: 907-915, 2004.

112.Lee MH, Ryu HM, Kim DJ, Lee BY, Cho EH, Yang JH, Kim MY, Han JY and Park SY: Rapid prenatal diagnosis of Down Syndrome using quantitative fluorescent PCR in uncultured amniocytes. J Korean Med Sci 19: 341-344, 2004. 